\section{PENDUGAAN AREA KECIL UNTUK ANGKA PARTISIPASI KASAR PENDIDIKAN DASAR DAN MENENGAH TINGKAT KABUPATEN/KOTA DI PROVINSI JAWA TENGAH TAHUN 2018}

(Small Area Estimation for Gross Enrollment Ratio of Primary and Secondary Education in District/City Level in Central Java Province, 2018)

\author{
Gusti Firmando1, Azka Ubaidillah² \\ 1,2Politeknik Statistika STIS \\ Jalan Otto Iskandardinata No. 64 C Jakarta Timur \\ E-mail: 16.9158@stis.ac.id
}

\begin{abstract}
ABSTRAK
Pada Maret tahun 2018, Angka Partisipasi Kasar (APK) di Indonesia untuk pendidikan dasar dan menengah adalah sebesar: APK SD/sederajat 108,61\%, APK SMP/sederajat 91,52\%, sedangkan APK SMA/sederajat 80,68\%. Capaian tersebut masih jauh dari target Rencana Pembangunan Jangka Menengah Nasional (RPJMN) 2014-2019. Salah satu provinsi yang memiliki APK pendidikan dasar dan menengah di bawah target adalah Provinsi Jawa Tengah. Upaya yang dapat dilakukan untuk mewujudkan target tersebut adalah dengan mengetahui capaian APK di level kabupaten/kota berdasarkan hasil Susenas September sehingga kontrol capaian pendidikan dapat dilakukan dua kali dalam setahun. Namun, langkah ini akan memerlukan penambahan jumlah sampel yang menyebabkan diperlukannya waktu, biaya, dan tenaga yang lebih besar. Untuk mengatasi hal tersebut, Small Area Estimation (SAE) dapat digunakan untuk menghasilkan presisi yang memadai. SAE merupakan metode pendugaan parameter-parameter subpopulasi yang memiliki ukuran sampel kecil. Metode SAE yang banyak digunakan adalah Empirical Best Linear Unbiased Predictor (EBLUP). Model ini belum memasukkan pengaruh spasial ke dalam model. Model Fay-Herriot yang memerhatikan efek spasial dikenal dengan Spatial Empirical Best Linear Unbiased Predictor (SEBLUP). Hasil penelitian menunjukkan bahwa kabupaten/kota yang memiliki APK pendidikan dasar dan menengah teringgi untuk tiap jenjang adalah: Kota Semarang (SD), Kabupaten Grobogan (SMP), dan Kota Salatiga (SMA). Sedangkan kabupaten/kota dengan APK pendidikan dasar dan menengah terendah untuk tiap jenjang adalah: Kabupaten Purworejo (SD), Kota Salatiga (SMP), dan Kabupaten Pekalongan (SMA). Metode EBLUP memiliki presisi yang lebih baik dalam mengestimasi APK SD/sederajat dan APK SMA/sederajat, dan metode SEBLUP lebih baik dalam mengestimasi APK SMP/sederajat.
\end{abstract}

Kata kunci: APK, SAE, EBLUP, SEBLUP

\title{
ABSTRACT
}

In March 2018, the Gross Enrollment Ratio (GER) in Indonesia for primary and secondary education was: $108.61 \%$ for elementary school, $91.52 \%$ for Junior High School, and $80.68 \%$ for Senior High School. This achievement is still far from the target of the 2014-2019 National Medium-Term Development Plan (RPJMN). One of the provinces that has a lower primary and secondary education GER is Central Java Province. Efforts that can be made to achieve this target are by knowing the achievement of GER at the district/city level based on the results of the September Susenas so that education achievement can be controlled twice a year. However, this step will require an increase in the number of samples which results in the need for more time, cost and energy. To overcome this, Small Area Estimation (SAE) can be used to produce sufficient precision. SAE is a method of estimating the parameters of a subpopulation with a small sample size. The SAE method that is widely used is the Empirical Best Linear Unbiased Predictor (EBLUP). This model does not include spatial influence into the model. The Fay-Herriot model that also consider spatial effects is known as the Spatial Empirical Best Linear Unbiased Predictor (SEBLUP). Results showed that districts/cities that had high GER for primary and secondary education are: Semarang, Grobogan, and Salatiga. Meanwhile, districts/cities with low GER are: Purworejo, Salatiga, and Pekalongan. The EBLUP method has better precision in estimating GER for elementary and senior high school, and the SEBLUP method is better at estimating GER for junior high school.

Keywords: GER, SAE, EBLUP, SEBLUP 


\section{PENDAHULUAN}

Pendidikan berperan penting dalam perubahan cara manusia hidup dan bertindak. Pendidikan menyebabkan manusia mampu menyesuaikan pola pikirnya terhadap berbagai peristiwa yang terjadi dalam kehidupannya.

Tujuan pembangunan di bidang pendidikan tertuang dalam Sustainable Development Goals (SDGs) tujuan keempat yaitu "Pendidikan berkualitas." Selain itu, Pasal 5 Undang-Undang Nomor 20 Tahun 2003 yang berbunyi "Setiap warga negara mempunyai hak yang sama untuk memperoleh pendidikan yang bermutu" mengamanatkan kepada pemerintah kewajiban untuk memastikan kesempatan belajar bagi warga negara dan menyediakan fasilitas pendidikan yang berkualitas.

Salah satu upaya peningkatan mutu pendidikan adalah dengan meningkatkan partisipasi pendidikan (Utami dan Wicaksono, 2019). Partisipasi pendidikan dapat di ukur dengan salah satu indikator pendidikan, yaitu Angka Partisipasi Kasar (APK). Angka Parisipasi Kasar merupakan proporsi jumlah penduduk yang sedang bersekolah pada suatu jenjang pendidikan terhadap jumlah penduduk usia sekolah yang sesuai dengan jenjang pendidikan tersebut.

Berdasarkan Potret Pendidikan Indonesia: Statistik Pendidikan Indonesia 2018, capaian APK di Indonesia pada tahun 2018 masih jauh dari target RPJMN 2014-2019. Salah satu provinsi yang memiliki APK pendidikan dasar dan menengah di bawah target adalah Provinsi Jawa Tengah. Jumlah penduduknya yang banyak menyebabkan provinsi ini memiliki sumbangan besar dalam penghitungan APK secara nasional. Sehingga, APK pendidikan dasar dan menengah Provinsi Jawa Tengah perlu dikaji lebih dalam.

Sampai saat ini, nilai APK dapat diperoleh melalui Susenas. Susenas dilakukan dua kali dalam setahun, Maret dan September. Namun, APK level kabupaten/kota hanya di peroleh dari Susenas Maret. Padahal, APK di bulan September perlu untuk diketahui, sebab nilainya akan berbeda di bandingkan Maret karena di tengah-tengah periode Maret-September biasanya terdapat program penerimaan peserta didik baru pada sekolah-sekolah di Indonesia. Sehingga, apabila capaian APK pada bulan September menurun dibandingkan bulan Maret, dapat dilakukan penanganan lebih lanjut dan lebih cepat. Tidak tersedianya data APK level kabupaten/kota pada hasil Susenas September disebabkan karena survei tersebut dirancang dengan ukuran sampel yang lebih kecil dibandingkan Susenas Maret dan di desain hanya untuk estimasi tingkat provinsi. Sehingga metode direct estimation (pendugaan parameter secara langsung) pada data Susenas September akan menghasilkan simpangan baku yang besar. Permasalahan ini (kurang sampel) dapat diatasi dengan penambahan jumlah sampel. Namun, cara ini akan menambah tenaga dan biaya yang diperlukan.

Untuk mengatasi hal tersebut, suatu metode estimasi tidak langsung yaitu Small Area Estimation (SAE) dapat digunakan untuk menghasilkan presisi yang memadai tanpa melakukan penambahan sampel. Menurut Rao (2003), SAE merupakan metode pendugaan parameter-parameter subpopulasi yang memiliki ukuran sampel yang tidak memungkinkan dilakukan direct estimation. Salah satu metode SAE yang banyak digunakan adalah Empirical Best Linear Unbiased Predictor (EBLUP). Model ini mengasumsikan random area effects tidak berkorelasi. Padahal, tidak menutup kemungkinan terdapat korelasi pada random area effects. Model SAE yang memerhatikan korelasi ini dikenal dengan Spatial Empirical Best Linear Unbiased Predictor (SEBLUP).

Berdasarkan pemaparan di atas, penelitian ini akan melakukan pendugaan APK pendidikan dasar dan menengah di Jawa Tengah pada tingkat kabupaten/kota melalui penerapan metode SAE. Dimana, yang di maksud pendidikan dasar dan menengah adalah pendidikan yang mencakup jenjang SD/sederajat, SMP/sederajat, dan SMA/sederajat. Dilakukan juga penghitungan direct estimation sebagai perbandingan. Dengan tujuan dari penelitian ini adalah: (1) mengestimasi APK pendidikan dasar dan menengah Provinsi Jawa Tengah pada level kabupaten/kota menggunakan metode SAE, (2) membandingkan hasil estimasi APK pendidikan dasar dan menengah di Provinsi Jawa Tengah antara direct estimation dan SAE, (3) mapping APK pendidikan dasar dan menengah Provinsi Jawa Tengah.

\section{METODE}

\section{Metode Pengumpulan Data}


Data yang digunakan dalam penelitian ini merupakan data sekunder berupa raw data Susenas September 2018 MSBP dan raw data Podes 2018, rincian penggunaan untuk masing-masing data yang digunakan adalah sebagai berikut:

1. Data yang digunakan dalam pendugaan langsung, yaitu APK pendidikan dasar dan menengah di Jawa Tengah, merupakan raw data Susenas 2018.

2. Data yang digunakan sebagai covariates merupakan raw data Podes 2018 . Hal ini disebabkan karena covariates tidak boleh memiliki measurement error, yang berarti, datanya harus merupakan data hasil sensus. Terdapat total 19 variabel Podes yang digunakan dalam penelitian ini, terdiri dari 1 variabel kategorik, 13 variabel numerik dan 5 variabel biner ada/tidak ada yang dianggap dapat menggambarkan APK pendidikan dasar dan menengah di Jawa Tengah. Deskripsi untuk masing-masing variabel adalah sebagai berikut:

\begin{tabular}{ccl}
\hline Variabel & \multicolumn{1}{c}{ Kategori isian } & \multicolumn{1}{c}{ Keterangan } \\
\hline$X_{1}$ & (1: lereng/puncak, 2: & Topografi wilayah desa \\
$X_{2}$ & lembah, 3: dataran) & Jumlah keluarga pengguna listrik \\
$X_{3}$ & & Jumlah lokasi permukiman di bantaran sungai \\
$X_{4}$ & & Jumlah lokasi permukiman kumuh \\
$X_{5}$ & & Jumlah keluarga permukiman kumuh \\
$X_{6 . S D}$ & & Jumlah jenjang pendidikan SD/sederajat \\
$X_{6 . S M P}$ & & Jumlah jenjang pendidikan SMP/sederajat \\
$X_{6 . S M A}$ & & Jumlah jenjang pendidikan SM/sederajat \\
$X_{7}$ & $(1:$ ada, 2: tidak ada) & Kegiatan pendidikan Paket A/B/C setahun terakhir \\
$X_{8}$ & & Jumlah fasilitas kesehatan \\
$X_{9}$ & & Jumlah tenaga medis yang menetap di desa/kelurahan \\
$X_{10}$ & & Jumlah SKTM yang dikeluarkan dea selama tahun 2017 \\
$X_{11}$ & & Jumlah desa dengan angkutan umum \\
$X_{12}$ & & Jumlah desa dengan warga pengguna HP \\
$X_{13}$ & & Jumlah desa yang memiliki sinyal internet \\
$X_{14}$ & $(1:$ ada, 2: tidak ada) & Kegiatan: sarana prasarana transportasi \\
$X_{15}$ & $(1:$ ada, 2: tidak ada) & Kegiatan: sarana prasarana sanitasi dan air bersih \\
$X_{16}$ & $(1:$ ada, 2: tidak ada) & Kegiatan: sarana prasarana pendidikan, kesehatan, dan \\
& & kebudayaan. \\
$X_{17}$ & $(1:$ ada, 2: tidak ada) & Kegiatan: pelayanan pendidikan, kesehatan, dan kebudayaan \\
& & masyarakat \\
\hline
\end{tabular}

3. Matriks pembobot spasial (contiguity matrix) diperoleh melalui pengkodean wilayah berdasarkan kedekatan dengan bantuan software GeoDa dan Microsoft Excel.

\section{Mapping (pemetaan)}

Dalam penelitian ini, mapping dilakukan dengan mengklasifikasikan hasil pendugaan menjadi dua kategori, yaitu: (1) daerah dengan warna lebih pekat menandakan APK melebihi target RPJMN 2015-2019, dan (2) daerah dengan warna yang tidak lebih pekat menandakan APK kurang dari target RPJMN 2015-2019.

\section{Empirical Best Linear Unbiased Predictor (EBLUP)}

Menurut Rao (2015), Small Area Estimation (SAE) merupakan teknik pendugaan parameter yang menggunakan pemodelan, dengan memanfaatkan data dari sensus atau catatan administrasi lainnya. Pendugaan ini dapat dilakukan sampai ke level area kecil. 
Secara umum, terdapat dua model dasar dalam SAE yaitu, model level wilayah (area leve) dan model level unit (unit leve). Pada penelitian ini, model yang digunakan adalah model level area karena data yang tersedia hanya sampai level area.

Model EBLUP dituliskan sebagai berikut:

dengan

$$
\hat{\theta}_{i}=\boldsymbol{x}_{\boldsymbol{i}}^{\boldsymbol{T}} \boldsymbol{\beta}+z_{i} v_{i}+e_{i}, \quad i=1,2, \ldots, m
$$

$\boldsymbol{x}_{\boldsymbol{i}}^{\boldsymbol{T}}$ : matriks variabel penyerta

$\boldsymbol{\beta}:\left(\beta_{0}, \ldots, \beta_{p}\right)^{T}$, vektor koefisien regresi berukuran $(p+1) \times 1$

$z_{i}:$ konstanta positif

$v_{i}:$ random effect dari small area

$m$ : banyaknya observasi

$v_{i}$ berdistribusi $N\left(0, \sigma_{v}^{2}\right)$ secara identik dan independen (iid.) dan $e_{i} \sim N\left(0, \psi_{i}\right)$ dengan varians $\psi_{i}$ diketahui dari data. Diasumsikan $v_{i}$ dan $e_{i}$ saling independen dengan $i$ melambangkan area. Ketika $\sigma_{v}^{2}$ diketahui, maka EBLUP menjadi estimator yang Best Linear Unbiased Predictor (BLUP):

$$
\begin{aligned}
& \theta_{i}^{B L U P}=\boldsymbol{x}_{\boldsymbol{i}}^{\boldsymbol{T}} \widetilde{\boldsymbol{\beta}}+\gamma_{i}\left(\hat{\theta}_{i}-\boldsymbol{x}_{\boldsymbol{i}}^{T} \widetilde{\boldsymbol{\beta}}\right) \\
& \theta_{i}^{B L U P}=\gamma_{i} \widehat{\theta}_{i}+\left(1-\gamma_{i}\right) \boldsymbol{x}_{\boldsymbol{i}}^{T}
\end{aligned}
$$

keterangan:

$\hat{\theta}_{i} \quad$ : estimasi langsung dari area ke- $i(i=1,2, \ldots, m)$

$\gamma_{i}: \frac{\sigma_{v}^{2}}{\psi_{i}+\sigma_{v}^{2}}$

$\sigma_{v}^{2} \quad$ : varians area random effect

$\psi_{i} \quad: \operatorname{MSE}\left(\hat{\theta}_{i}\right)$

$\boldsymbol{x}_{\boldsymbol{i}}^{\boldsymbol{T}} \quad$ : vektor variabel penyerta (covariates)

$\widetilde{\boldsymbol{\beta}} \quad$ : koefisien regresi

Dalam praktiknya, varians pengaruh acak $\left(\sigma_{v}^{2}\right)$ tidak diketahui, sehingga harus di estimasi terlebih dahulu. Sehingga diperoleh estimator baru, yaitu:

$$
\hat{\theta}_{i}^{E B L U P}=\hat{\gamma}_{i} \widehat{\theta}_{i}+\left(1-\hat{\gamma}_{i}\right) \boldsymbol{x}_{i}^{T} \widehat{\boldsymbol{\beta}} \text {. }
$$

\section{Spatial Empirical Best Linear Unbiased Predictor (SEBLUP)}

Model SEBLUP dikembangkan oleh beberapa peneliti, diantaranya adalah Petrucci dan Salvati (2006) dan Pratesi dan Salvati (2007) dengan mengasumsikan bahwa ketergantungan spasial yang dimasukkan kedalam komponen error dari random faktor mengikuti proses model Simultaneous Autoregressive (SAR). Model SAR diperkenalkan oleh Anselin (Anselin 1992), dimana $v$ memenuhi:

$$
v=\rho \boldsymbol{W}+\boldsymbol{u}
$$

keterangan:

$$
\begin{array}{ll}
\rho & : \text { koefisien spatial autoregressive } \\
\boldsymbol{W} & : \text { matriks pembobot spasial } \\
\boldsymbol{v} & : \text { vektor area random effect } \\
\boldsymbol{u} & : \text { vektor error dari area random effect, } u_{i} \sim N\left(0, \sigma_{u}^{2} I_{m}\right)
\end{array}
$$

Koefisien SAR menunjukkan kekuatan hubungan spasial antar area random effect, nilainya berkisar antara -1 sampai 1 . Nilai $\rho$ yang positif menandakan bahwa suatu area dengan nilai parameter yang tinggi cenderung dikelilingi oleh area lain dengan parameter yang tinggi pula dan suatu area dengan nilai parameter yang rendah cenderung dikelilingi oleh area lain dengan parameter yang rendah. Sebaliknya, nilai $\rho$ yang negatif menandakan bahwa suatu area dengan nilai parameter yang tinggi cenderung dikelilingi oleh area lain dengan parameter yang rendah dan suatu area yang parameternya rendah cenderung dikelilingi oleh area lain dengan parameter yang tinggi (Savitz dan Rauduenbush, 2009).

Estimator Spasial BLUP untuk parameter $\theta_{i}$ dengan $\sigma_{u}^{2}, \sigma_{v}^{2}$, dan $\rho$ yang diketahui adalah:

$$
\begin{array}{r}
\tilde{\theta}_{i}^{S}\left(\sigma_{u}^{2}, \rho\right)=\boldsymbol{x}_{\boldsymbol{i}} \widehat{\boldsymbol{\beta}}+\boldsymbol{b}_{\boldsymbol{i}}^{T}\left\{\sigma_{u}^{2}\left[(\boldsymbol{I}-\boldsymbol{\rho} \boldsymbol{W})(\boldsymbol{I}-\boldsymbol{\rho} \boldsymbol{W})^{\boldsymbol{T}}\right]^{-1}\right\} \boldsymbol{Z}^{\boldsymbol{T}} \times\left\{\psi_{i}+\right. \\
\boldsymbol{Z} \sigma_{u}^{2}\left[(\boldsymbol{I}-\boldsymbol{\rho} \boldsymbol{W})(\boldsymbol{I}-\boldsymbol{\rho} \boldsymbol{W})^{T}\right]^{-1}(\widehat{\theta}-\boldsymbol{X} \widehat{\boldsymbol{\beta}}) \ldots \ldots \ldots \ldots \ldots \ldots \ldots \ldots \ldots \ldots \ldots \ldots \ldots \ldots \ldots \ldots \ldots \ldots
\end{array}
$$

keterangan:

$$
\hat{\beta} \quad:\left(X^{T} V^{-1} X\right)^{-1} X^{T} V^{-1} \widehat{\theta}
$$


$b_{i}^{T} \quad$ : vektor berukuran $1 \times n(0,0, \ldots 0,1,0, \ldots 0)$

\section{Angka Partisipasi Kasar}

Angka Parisipasi Kasar merupakan proporsi jumlah penduduk yang sedang bersekolah pada suatu jenjang pendidikan terhadap jumlah penduduk usia sekolah yang sesuai dengan jenjang pendidikan tersebut. Secara umum, APK digunakan untuk mengukur keberhasilan program pembangunan pendidikan yang diselenggarakan dalam rangka memperluas kesempatan bagi penduduk untuk mengenyam pendidikan (BPS, 2018). Terdapat empat jenis APK yaitu, APK SD/sederajat, APK SMP/sederajat, APK SMA/sederajat dan APK PT. Dalam penelitian ini, yang tercakup dalam APK pendidikan dasar dan menengah merupakan APK SD/sederajat, APK SMP/sederajat, dan APK/SMA sederajat. Rumus untuk menghitung masing-masing APK tersebut adalah:

$$
\begin{aligned}
& A P K S D / \text { sederajat }=\frac{\text { Jumlah murid } S D \text { sederajat }}{\text { Jumlah penduduk usia } 7-12 \text { tahun }} \times 100 \% \ldots . \\
& A P K S M P / \text { sederajat }=\frac{\text { Jumlah murid SMP sederajat }}{\text { Jumlah penduduk usia } 13-15 \text { tahun }} \times 100 \% \\
& A P K S M A / \text { sederajat }=\frac{\text { Jumlah murid SMA sederajat }}{\text { Jumlah penduduk usia } 16-19 \text { tahun }} \times 100 \%
\end{aligned}
$$

\section{Uji Autokorelasi Spasial}

Untuk mengidentifikasi ada tidaknya korelasi antara area random effect, dilakukan uji autokorelasi spasial dengan menggunakan statistik Moran's I. Ringkasan hasil uji di sajikan pada Tabel 4. Jika terdapat autokorelasi spasial, maka pendugaan dilanjutkan dengan menggunakan SEBLUP. Nilai statistik Moran's I berkisar antara -1 (strong negative spatial autocorrelation) sampai 1 (strong positive spatial autocorrelation). Jika nilai koefisien Moran's I sama dengan nol, maka tidak terdapat autokorelasi spasial pada data.

Rumus uji Moran's I adalah:

$$
I_{M O}=\frac{\sum_{i=1}^{m} \sum_{j=1}^{m} w_{i j}\left(y_{i}-\bar{y}\right)\left(y_{j}-\bar{y}\right)}{\sum_{i=1}^{m}\left(y_{i}-\bar{y}\right)^{2}}
$$

\section{keterangan:}

$y_{i} \quad$ : nilai observasi suatu lokasi

$y_{j} \quad$ : nilai observasi di lokasi lain

$\bar{y} \quad$ : rata-rata variabel y

$w_{i j} \quad$ : pembobot antar wilayah

\section{RRMSE}

Evaluasi hasil kajian dapat di lakukan dengan membandingkan nilai RRMSE dari metode yang digunakan, nilai RRMSE diperoleh dengan membagi akar kuadrat dari MSE suatu pendugaan terhadap nilai hasil pendugaan.

$$
R R M S E=\frac{\sqrt{\operatorname{MSE}(\widehat{\theta})}}{\widetilde{\theta}} \times 100 \%
$$

\section{HASIL DAN PEMBAHASAN}

Estimasi Langsung APK Pendidikan Dasar dan Menengah 
Pada penelitian ini, estimasi langsung dilakukan pada level wilayah kabupaten/kota, Jumlah kabupaten/kota yang terdapat di Jawa Tengah adalah sebanyak 35 kabupaten/kota.

Tabel 1. Nilai-nilai statistik APK Pendidikan Dasar dan Menengah Berdasarkan Direct Estimation

\begin{tabular}{lccc}
\hline Statistik & APK SD/sederajat & APK SMP/sederajat & APK SMA/sederajat \\
\hline $\mathrm{N}$ & 35 kabupaten/kota & 35 kabupaten/kota & 35 kabupaten/kota \\
Rata-Rata & $114,84 \%$ & $97,51 \%$ & $94,95 \%$
\end{tabular}

\begin{tabular}{lccc}
\hline Statistik & APK SD/sederajat & APK SMP/sederajat & APK SMA/sederajat \\
\hline Min & $101,5 \%$ & $63,59 \%$ & $52,09 \%$ \\
Max & $127,64 \%$ & $147,33 \%$ & $161,95 \%$ \\
Range & $26,14 \%$ & $83,74 \%$ & $109,86 \%$ \\
\hline
\end{tabular}

Berdasarkan tabel nilai-nilai statistik di atas dapat diketahui bahwa di Jawa Tengah, rata-rata APK untuk jenjang SD/sederajat adalah sebesar 114,84\%, jenjang SMP/sederajat sebesar 97,51\% dan jenjang SMA/sederajat sebesar 94,95\%. Dari ketiga nilai tersebut, yang masih belum mencapai target RPJMN 2015-2019 adalah APK untuk jenjang pendidikan SMP/sederajat. Namun, walaupun rata-rata nilai APK untuk jenjang SD/sederajat dan SMA/sederajat sudah melampaui target, masih banyak wilayah yang APKnya berada di bawah target tersebut. Selain itu, range yang besar mengindikasikan bahwa terdapat kesenjangan antar daerah.

\section{Estimasi APK dengan Metode EBLUP}

Tahapan selanjutnya adalah menerapkan prosedur stepwise, kemudian melanjutkannya ke tahap estimasi dengan metode EBLUP. Dari variabel-variabel yang dianggap dapat menjelaskan APK di Jawa Tengah, setelah dilakukan proses stepwise diperoleh variabel-variabel sebagai berikut:

Tabel 2. Ringkasan Hasil Stepwise

\begin{tabular}{cccccc}
\hline \multicolumn{2}{c}{ SD/Sederajat } & \multicolumn{2}{c}{ SMP/Sederajat } & \multicolumn{2}{c}{ SMA/Sederajat } \\
\hline Variabel & $p$-value & Variabel & $p$-value & Variabel & $p$-value \\
\hline (intersep) & $0,0000^{*}$ & (intersep) & $0,0000^{*}$ & (intersep) & $0,0000^{*}$ \\
$X_{5}$ & $0,002^{*}$ & $X_{1 . \text { Lereng }}$ & $0,0611^{*}$ & $X_{1 . D a t a r a n}$ & $0,0067^{*}$ \\
$X_{6 . S D}$ & $0,0561^{*}$ & $X_{1 . \text { Lembah }}$ & $0,0191^{*}$ & $X_{3}$ & $0,0094^{*}$ \\
$X_{10}$ & $0,008^{*}$ & $X_{1 . \text { Dataran }}$ & $0,0047^{*}$ & $X_{4}$ & $0,0009^{*}$ \\
$X_{12}$ & $0,0191^{*}$ & $X_{3}$ & $0,0043^{*}$ & $X_{8}$ & $0,0064^{*}$ \\
$X_{13}$ & $0,0174^{*}$ & $X_{4}$ & $0,0046^{*}$ & & \\
$X_{14}$ & $0,0111^{*}$ & $X_{12}$ & $0,0047^{*}$ & & \\
$X_{16}$ & 0,3357 & & & \\
\hline
\end{tabular}

Keterangan: (*) signifikan pada $\alpha=0,1$

Variabel-variabel tersebut kemudian digunakan untuk melakukan pendugaan dengan metode SAE. Hasil pendugaan dengan metode EBLUP untuk APK pendidikan dasar dan menengah di Jawa Tengah adalah sebagai berikut:

Tabel 3. Nilai-Nilai Statistik Berdasarkan Metode EBLUP

\begin{tabular}{lccc}
\hline \multicolumn{1}{c}{ Statistik } & SD/sederajat & SMP/sederajat & SMA/sederajat \\
\hline$N$ & 35 & 35 & 35 \\
Rata-Rata & $112,73 \%$ & $96,19 \%$ & $94,24 \%$ \\
Minimum & $98,96 \%$ & $74,17 \%$ & $67,28 \%$ \\
Maksimum & $128,65 \%$ & $131,06 \%$ & $155,19 \%$ \\
Range & $29,69 \%$ & $56,89 \%$ & $87,91 \%$ \\
\hline
\end{tabular}


Dari Tabel 3 diketahui bahwa rata-rata APK berdasarkan metode EBLUP untuk jenjang SD/sederajat adalah sebesar 112,73\%, jenjang SMP/sederajat sebesar 96,19\% dan jenjang SMA/sederajat sebesar 94,24\%. Rata-rata capaian APK untuk SD/sederajat dan SMP/sederajat berada di bawah target RPJMN 2015-2019, sedangkan rata-rata APK jenjang SMA/sederajat sudah melebihi target RPJMN. Namun, walaupun APK SMA/sederajat secara rata-rata sudah berada di atas target, masih banyak kabupaten/kota yang APKnya masih di bawah target. Hal ini dapat diketahui dengan melihat mapping.

Perbandingan nilai APK SD/sederajat berdasarkan ketiga metode dapat dilihat berdasarkan grafik berikut. Hasil pendugaan dengan direct estimation berwarna biru sedangkan hasil pendugaan dengan metode EBLUP berwarna orange.
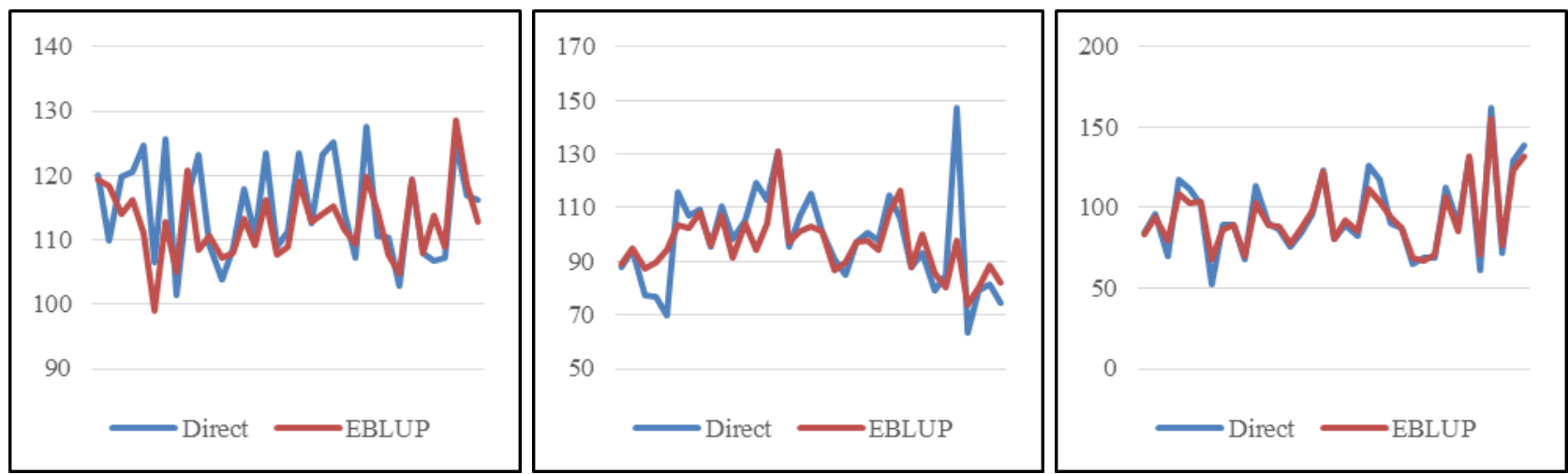

Gambar 1. Grafik perbandingan APK Pendidikan Dasar dan Menengah, Direct Estimation dan EBLUP (kiri ke kanan: SD/sederajat, SMP/sederajat, SMA/sederajat)

Dari grafik diketahui bahwa hasil pendugaan dengan metode EBLUP memiliki fluktuasi yang lebih rendah dibanding direct estimation. Mapping APK pendidikan dasar dan menengah untuk tiap jenjang dapat dilihat pada gambar berikut:
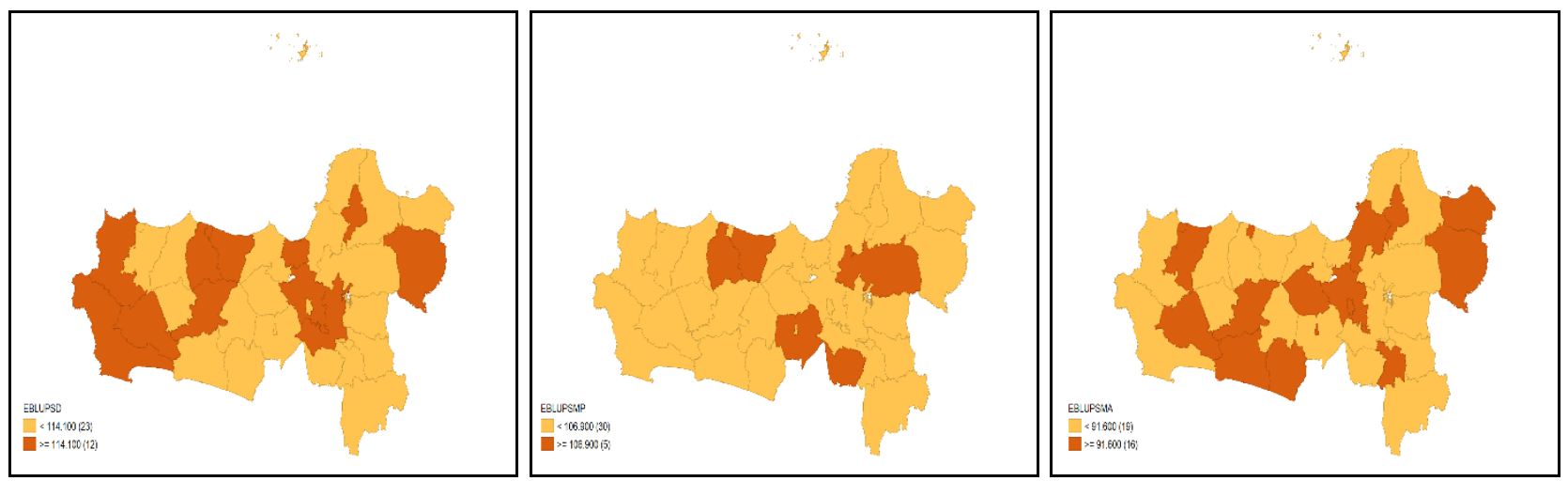

Gambar 2: Pemetaan APK Pendidikan Dasar dan Menengah, EBLUP

Pada jenjang APK SD/sederajat, terdapat 12 kabupaten/kota yang sudah melebihi target RPJMN 2015-2019, jenjang SMP/sederajat sebanyak 5 kabupaten/kota. sedangkan jenjang SMA/sederajat sebanyak 16 kabupaten/kota. Dari hasil mapping diketahui bahwa masih terdapat kesenjangan capaian APK pendidikan dasar dan menengah level kabupaten/kota di Jawa Tengah.

\section{Uji Autokorelasi Spasial}

Setelah dilakukan direct estimation, dilakukan uji autokorelasi random error untuk mengetahui ada tidaknya efek spasial. Jika ada, pendugaan dilanjutkan dengan menggunakan metode SEBLUP. Ringkasan hasil uji disajikan pada tabel berikut:

Tabel 4. Ringkasan Hasil Uji Autokorelasi Spasial

\begin{tabular}{cll}
\hline Jenjang & Moran's I & $p$-value \\
\hline SD & $-0,01822$ & 0,4615
\end{tabular}




\begin{tabular}{ccc} 
SMP & 0,1687 & $0,0395^{*}$ \\
SMA & $-0,0062$ & 0,4191 \\
\hline
\end{tabular}

Keterangan: $\left(^{*}\right)$ signifikan pada $\alpha=0,1$

Dari tabel tersebut, dapat disimpulkan bahwa terdapat efek spasial pada jenjang SMP/sederajat, sehingga estimasi APK SMP/sederajat dilanjutkan dengan metode SEBLUP.

\section{Estimasi APK SMP/sederajat dengan Metode SEBLUP}

Untuk melakukan pendugaan dengan metode SEBLUP, diperlukan suatu matriks khusus yaitu matriks pembobot spasial. Pembobot spasial yang digunakan dalam dalam penelitian ini adalah matriks pembobot spasial yang bertipe queen contiguity. Aturan yang berlaku dalam dalam menggunakan matriks contiguity tipe queen adalah apabila suatu wilayah lain berada tepat di sekitar (bersinggungan) suatu wilayah yang di observasi, maka wilayah tersebut diberikan kode satu (1), sedangkan jika tidak bersinggungan, wilayah tersebut diberikan kode nol (0).

Tahapan selanjutnya adalah menerapkan metode SEBLUP. Berikut merupakan nilai-nilai statistik yang diperoleh dengan penerapan metode SEBLUP:

Tabel 5. Nilai-nilai statistik berdasarkan metode SEBLUP

\begin{tabular}{lc}
\hline \multicolumn{1}{c}{ Statistik } & APK SMP/sederajat \\
\hline$N$ & 35 \\
Rata-Rata & $95,17 \%$ \\
Minimum & $76,69 \%$ \\
Maksimum & $131,06 \%$ \\
Range & $54,37 \%$ \\
\hline
\end{tabular}

Dari Tabel 5 diketahui bahwa rata-rata APK berdasarkan metode SEBLUP untuk jenjang SMP/sederajat sebesar 95,17\%. Nilai ini masih berada di bawah target RPJMN 2015-2019. wilayah dengan capaian APK SMP/sederajat terendah adalah Kota Salatiga, sedangkan wilayah dengan capaian APK SMP/sederajat tertinggi adalah Kabupaten Grobogan.

Perbandingan grafik APK SMP/sederajat berdasarkan direct estimation, EBLUP, dan SEBLUP disajikan pada gambar di bawah.

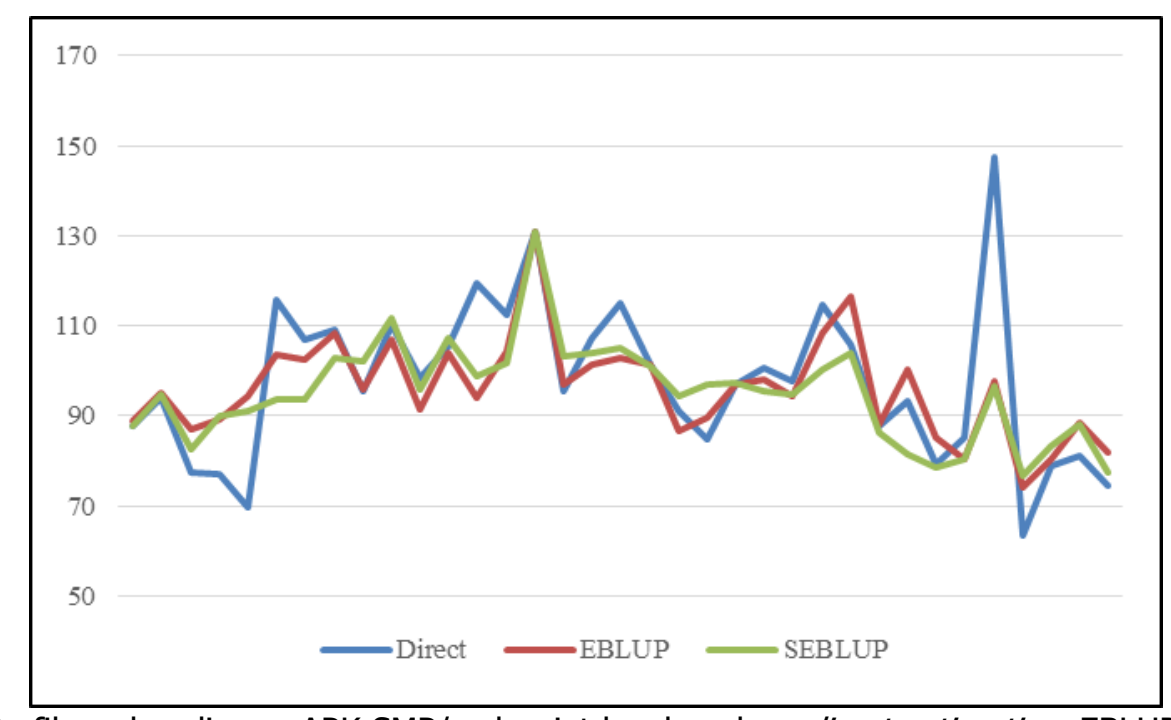

Gambar 3: Grafik perbandingan APK SMP/sederajat berdasarkan direct estimation, EBLUP, dan SEBLUP

Dengan melihat grafik di atas, diketahui bahwa hasil estimasi dengan menggunakan metode SEBLUP memiliki fluktuasi yang lebih rendah. Hal ini mengindikasikan bahwa metode SEBLUP lebih baik dalam mengestimasi APK SMP/sederajat. 
Mapping hasil estimasi APK SMP/sederajat level kabupaten/kota berdasarkan metode SEBLUP disajikan pada Gambar 4. Terlihat bahwa hanya terdapat tiga kabupaten/kota yang APK SMP/sederajatnya sudah melebihi target RPJMN 2015-2019. Capaian yang sangat rendah ini menunjukkan bahwa diperlukan perhatian yang lebih pada partisipasi pendidikan jenjang SMP/sederajat level kabupaten/kota di Jawa Tengah.

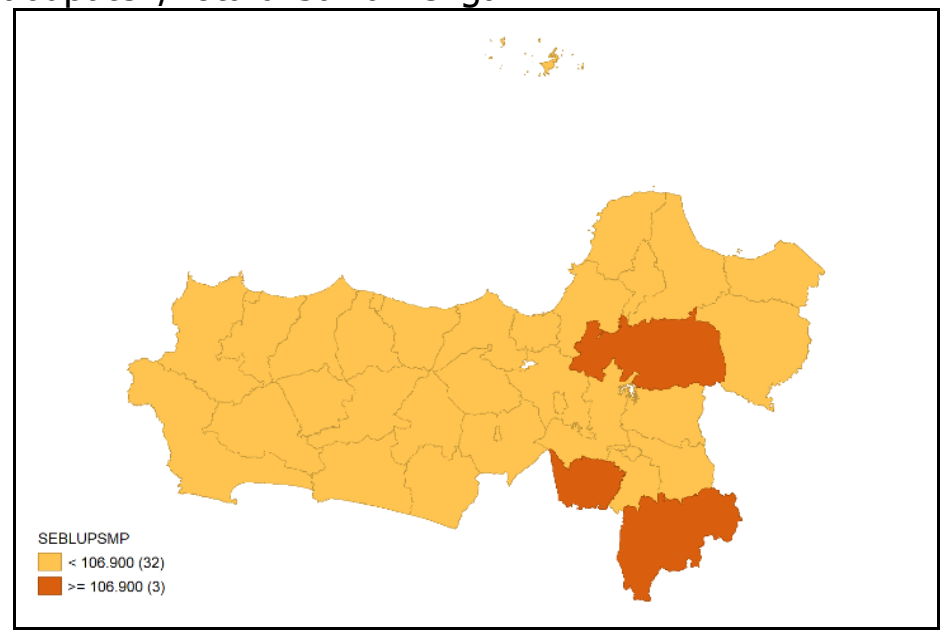

Gambar 4: Mapping APK SMP/sederajat berdasarkan metode SEBLUP

\section{Perbandingan RRMSE Direct Estimation dan SAE}

Untuk menentukan metode estimasi yang memberikan hasil pendugaan terbaik, dilakukan perbandingan nilai RRMSE. Perbandingan nilai RRMSE masing-masing metode untuk APK tiap jenjang dapat dilihat pada tabel di bawah. Metode direct estimation diwakili dengan boxplot berwarna biru, metode EBLUP dengan warna orange, sedangkan metode SEBLUP dengan warna abu-abu.
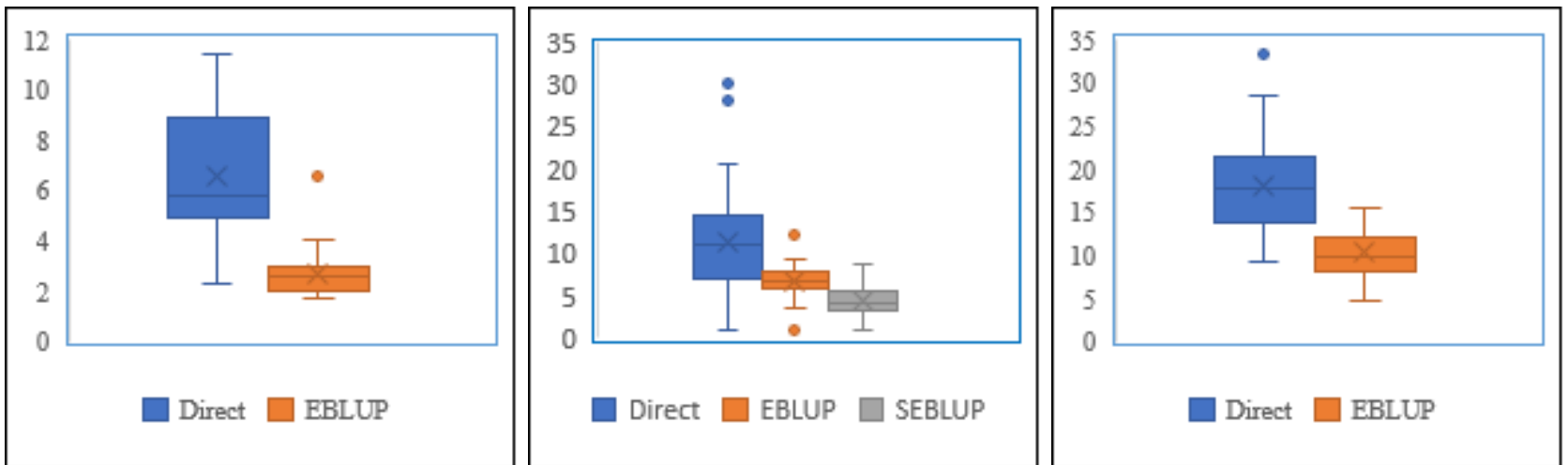

Gambar 5: Boxplot Perbandingan RRMSE Direct Estimation dan SAE

(kiri ke kanan, SD/sederajat, SMP/sederajat, SMA/sederajat)

Berdasarkan boxplot tersebut terlihat bahwa untuk jenjang SD/sederajat dan SMA/sederajat, metode EBLUP memiliki tingkat presisi yang lebih baik dibandingkan dengan direct estimation. Untuk jenjang SMP/sederajat, metode yang memiliki presisi terbaik adalah metode SEBLUP. Berikut merupakan grafik RRMSE: 


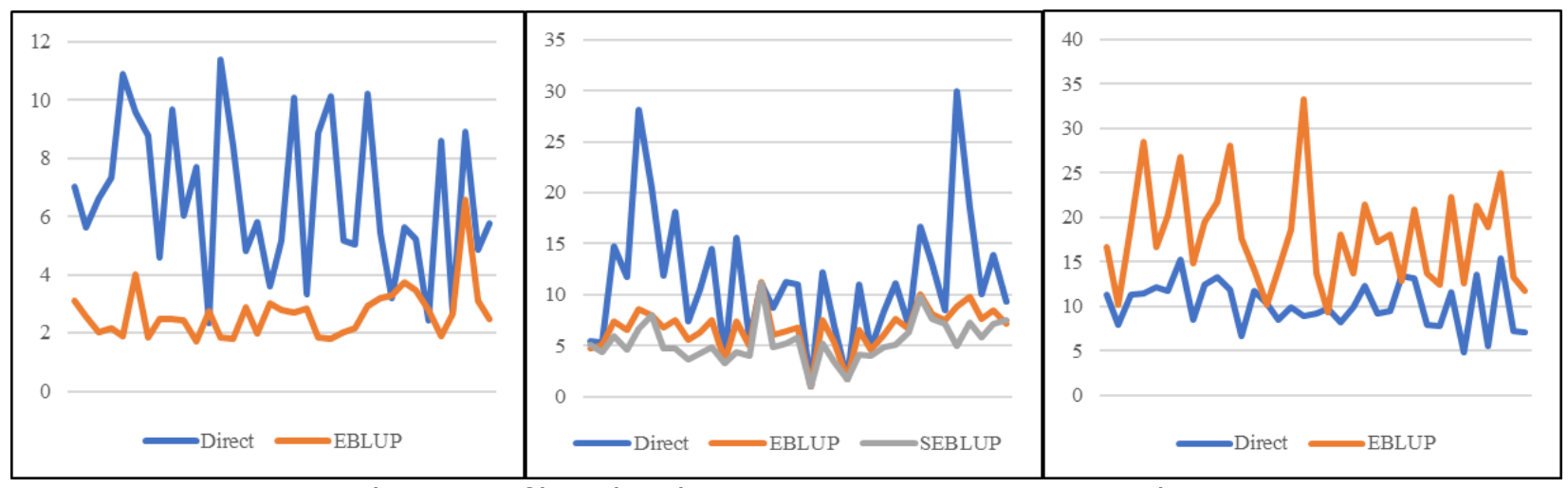

Gambar 6: Grafik Perbandingan RRMSE Direct Estimation dan SAE

(kiri ke kanan, SD/sederajat, SMP/sederajat, SMA/sederajat)

Sesuai dengan perbandingan berdasarkan boxplot, metode SAE memiliki tingkat presisi yang lebih baik dibandingkan dengan direct estimation. Hal ini sejalan dengan penelitian-penelitian yang telah dilakukan sebelumnya mengenai metode SAE.

\section{KESIMPULAN}

Berdasarkan hasil penelitian, dapat disimpulkan bahwa:

1. Capaian Angka Partisipasi Kasar pendidikan dasar dan menengah beberapa kabupaten/kota di Jawa Tengah masih jauh dari target RPJMN 2015-2019, terutama pada jenjang SMP/sederajat.

2. Dalam mengestimasi APK pendidikan dasar dan menengah level kabupaten/kota di Jawa Tengah, metode yang terbaik untuk melakukan pendugaan parameter APK SD/sederajat dan APK SMA/sederajat adalah metode EBLUP. Sedangkan APK SMP/sederajat paling baik di estimasi dengan menggunakan metode SEBLUP. Secara umum, metode SAE lebih baik dari direct estimation.

3. Berdasarkan mapping dapat diketahui bahwa untuk masing-masing jenjang diperoleh hasil yaitu: i) terdapat sebanyak dua belas kabupaten/kota yang APK SD/sederajatnya sudah mencapai target RPJMN 2015-2019, ii) jenjang SMP/sederajat terdapat tiga kabupaten/kota yang mencapai target, sedangkan pada iii) jenjang SMA/sederajat terdapat enam belas kabupaten/kota. Dari hasil ini, diketahui bahwa dari total keseluruhan kabupaten/kota yang ada (35 48 kabupaten/kota), hanya terdapat kurang dari setengah kabupaten/kota yang memiliki APK pendidikan dasar dan menengah di atas target RPJMN 2015-2019

\section{DAFTAR PUSTAKA}

Anselin, L. (1988). "Spatial Econometrics: Methods and Models". Kluwer Academic Publishers, Dordrecht.

Badan Pusat Statistik. (2018). Potret Pendidikan Indonesia Statistik Pendidikan 2018. Jakarta.

Badan Pusat Statistik. (2018). Statistik Penunjang Pendidikan 2018. Jakarta.

Badan Pusat Statistik Provinsi Jawa Tengah. (2018). Statistik Pendidikan Provinsi Jawa Tengah 2018. Jawa Tengah.

Chandra, H. (2013). Exploring spatial dependence in area-level random effect model for disaggregate-level crop yield estimation. Journal of Applied Statistics.

Dubin R. (2009). Spatial Weight. Fotheringham AS. PA Rogerson. editor, Handbook of Spatial Analysis. London: Sage Publications.

Ghosh M, Rao JNK. (1994). Small area estimation: an appraisal (with discussion). Statistical Science.

Petrucci A, Salvati N. (2004). Small area estimation using spatial information. The Rathbun lake watershed case study. Dipartinto di Statistica "G. Parenti" viale Morgagni.

Petrucci A, Salvati N. (2006). "Small Area Estimation for Spatial Correlation in Watershed Erosion Assessment". Journal of Agricultural, Biological, and Environmental Statistics 11:2:169-18.

Pratesi M, Salvati N. (2008). Small area estimation: the EBLUP estimator based on spatially correlated 
random area effects. Statistical methods and applications. Stat. Meth. \& Appl.

Rao, JNK. (2003). Small Area Estimation. New York: John Wiley and Sons.

Rao JNK, Molina I. (2015). Small Area Estimation, second edition. New York: John Wiley and Sons.

Savitz NV, Raudenbush SW. (2009). Exploiting spatial dependence to improve measurement of neighborhood social processes. Sociological Methodology.

Utami ED, Wicaksono F "Determinan Partisipasi Sekolah di Indonesia: Analisis Data Susenas Tahun 2017. Jurnal IImiah WIDYA Non-Eksakta 1:1:68-73 